\title{
Journeys of Becoming: Hair, the Blogosphere and Theopoetics in Chimamanda Ngozi Adichie's Americanah
}

\section{ABSTRACT}

Chimamanda Ngozi Adichie's novel Americanab provides provocative reflections on intertextuality and becoming by exploring the potentially transformative power of "blog-writing." Through a combined reading of Mayra Rivera's Poetics of the Flesh and Adichie's Americanah, this article details intersections between the virtual and the material; writing in the (imagined "other-wordly") blogosphere about the organic matter of hair. The narrator of the novel, Ifemelu, establishes a blog after she shares her story to decide to stop using relaxants and to allow her hair to be natural, via an online chat-room; she refuses to go through ritual performances in order to succeed as a migrant in America. In this article I argue that Adichie's detailing of Ifemelu's relationship with her hair explores the way in which creative practice, or poetics, is intimately connected to the journey of our flesh; social history is marked on our bodies. The blog becomes a confessional which details the demeaning effect that social constructions of race have had on her body. But the blog ultimately becomes self-destructive. It is only when Ifemelu returns to Nigeria that she embodies the transformative and cathartic power of contemporary modes of story-telling, and where she is finally able to "spin herself into being."

Keywords: Adichie, theopoetics, materiality, hair, blog-writing. 
When you write, it's like braiding your hair. Taking a bandful of coarse unruly strands and attempting to bring them unity. Your fingers have still not perfected the task. Some of the braids are long, others short. Some are thick, others thin. Some are heavy. Others are light. Like the diverse women in your family. Those whose fables and metaphors, whose similes, and soliloquies, whose diction and "je ne sais quoi" daily slip into your survival soup, by way of their fingers. (Danticat 192)

\section{INTRODUCTION}

This article will focus on the motif of hair braiding that is adopted by Chimamanda Ngozi Adichie in her novel Americanah, to explore the ways in which contemporary discursive practices (in this context, blog writing) are intimately connected to the experiences of bodies (such as black women's hair movements). This trope becomes even more powerful when thinking about gendered and racialized bodies that are perpetually forced to re-enact histories of colonialism, slavery, Christian imperialism and civility via neo-colonial systems of "body shaming" (such as natural black hair as a symbol of barbarity). The weaving of hair alongside the weaving of a story is a poignant motif for exploring issues of intertextuality, gender, race and material religion, as well as (I will argue) being an intriguing act of "theopoiesis." This article will therefore address the following three issues through a reading of Americanab: (1) the motif of hair braiding allows Adichie to anchor the potentially transcendent blogosphere in the experiences of the black female body; (2) is the "blogosphere" a testimonial and transcendent space where you can find your voice and liberation by identifying your community or will cyberspace always risk "replicating the hierarchies of classical imperialism"? (Isaacs 187); (3) the third element (or section of hair in the braid) of the article binds these two issues together, and provides a new and distinct reading of how the motif of hair braiding and hair politics functions in Adichie's work. I will refer to the theopoetics movement as imagined by the work of Catherine Keller and Mayra Rivera. Liberation and postcolonial theologian, Mayra Rivera, also reminds us that all social discourses are intimately linked to corporality and materiality: "This body that I am, at this moment, did not exist before the world that has shaped it ... My becoming is dependent on and bound to other bodies" (Rivera, Poetics of the Flesh 144). This idea is particularly poignant in the context of race and gender and when, as in the case of Adichie's work, the "social discourse" is the genre of blog writing and cyberspace. Adichie's language, when describing the blog-writing process, details vivid images of flesh, corporality but also "theos" and transcendence, but transcendence that can be realized in not beyond the body. I will detail the journey of Ifemelu's becoming (or "incarnation," as Rivera would say) in order to 
show the intimate bodily link between the liberatory and communal yet painful acts of hair weaving, story-telling via cyber-space, and, arguably, what Catherine Keller calls "God-making” (Keller 105-18).

\section{THEOPOETICS}

In the epilogue to her collection of short stories Krik? Krak! the Haitian author Edwidge Danticat reflects (through a narrator) upon the social shame of a woman becoming a writer. The act of writing, perceived as an act of immateriality, could be seen as undermining the memory of the generations of hardworking women, intimately connected by domestic labour and acts of speech. Danticat complicates this mind-body dualism (the act of writing stories with pen and paper vs. living stories immortalized in shared acts of cooking or labour) by detailing her own act of writing as being an intimate continuation of the generations of female bodies engaged in what Rivera calls "social materiality" (Poetics of the Flesh 149). The phrase "you remember thinking while braiding your hair that you look a lot like your mother" (Danticat 191-96) is repeated at the beginning of each paragraph. The final paragraph says:

Your mother, she introduced you to the first echoes of the tongue that you now speak when at the end of the day she would braid your hair while you sat between her legs scrubbing the kitchen pots. While your fingers worked away at the last shadows of her day's work, she would make your braids Sunday-pretty even during the week.

When she was done she would ask you to name each braid after those nine-hundred and ninety-nine women who were boiling in your blood, and since you had written them down and memorized them, the names would come rolling off your tongue. And this was your testament to the way that these women lived and died and lived again. (195-96)

The narrator of Danticat's epilogue (or the author's own words to her mother) testifies that her discursive practice (writing with pen and paper) is her only way to ensure that the memories of the "nine hundred and ninety-nine women" will survive through the imperfect words she weaves for "when you write it is like braiding hair." The words she weaves are "like the diverse women in your life ... whose diction ... daily slip into your survival soup, by way of their fingers" (Danticat 192). Her survival, and many like her, is ensured by weaving the past into the formation of stories of the present. And this process is necessarily a bodily practice. The intimacy of this discourse, which Danticat describes as a testament, is arguably theopoetics. 
Catherine Keller traces the history of theopoetics to ancient Greek: "As poiesis means making or creation, so theopoiesis gets rendered as 'God-making' or 'becoming divine'” (Keller 107). Keller details the early Christian emphasis on the dependency of "God" on human creation. This history of God-making is lost during the journey of Christianity, particularly Protestantism (108). She does not want to idealize this ancient Christian tradition but rather to "amplify counterpoint resonances working within a received tradition" (108), and so to provide historical depth to the recent movement to understand certain social discourse and poetics as God-making, or theopoiesis. "Theopoetics" is often considered a relatively recent term, and movement within theology. Interestingly, Keller herself admits to believing she coined the phrase herself in the 2000 s only to find out that theopoetics had been used by liberal theologians at her own institution, Harvard, in the 1960s (110). Theopoetics in its new millennial form arrived via feminist and liberation theology which has always "experimented" with a "new poiesis of the divine itself-making God black, female, poor, queer, animal, and so-on" (115). In the march towards the complete negation of God, "theos ... remains a cloudy mirror" and "poiesis means materialization" (115). Keller understands the cosmos as an ambiguous entity which is always involved in the act of creation, rather than a single event, via the web of human interconnectedness. She describes this as "material entanglement" (115). Theopoetics is, therefore, an act of Godmaking, capturing "theos" in all its earthly and human manifestations and entanglements.

Mayra Rivera calls this entanglement "poetics of the flesh." Importantly, Rivera sees Caribbean writing as a distinct poetics (Rivera, Poetics Ashore 242). ${ }^{1}$ Poetics has an ontological function that "refers not only to styles of writing but to modes of knowing, being, and acting in the world" (242). Caribbean history of loss and survival, death and rebirth, bring "theos" and "poiesis" together. Danticat's poiesis of naming each braid after the women who are "boiling in your blood," whose names you have memorized because you have written them down with pen and paper is testament to this. As Rivera says, "words weave the flesh of the world" (Poetics of the Flesh 113) and "social structures" such as race and gender "form the world from which our flesh is woven" (114). The image of nine hundred and ninety-nine women boiling in the blood of Danticat

1 "The catastrophe of the middle passage and the ongoing devastations of colonialism are ever present in these works, as reminders that the very existence of Caribbean peoples is a testimony to the power of their creativity under the worse possible circumstances, of their embodied poetics" (Rivera, "Poetics Ashore" 243). 
details the anguish of a long history which will always form her own flesh and words. Similarly, Adichie's language, when describing the blog writing process, details vivid images of flesh and corporality. Initially, Ifemelu feels "revived" by the process, like she was "giving testimony in church" (Adichie 213). ${ }^{2}$ But after many years this becomes destructive. The physical discomfort Ifemelu feels in her own body, and that of those she writes about, is evident; whilst having her hair braided in a salon in Princeton before returning to Nigeria, she reflects that it felt like she was "hacking into the carcass of people's stories ... Each post scraped off yet one more scale of self until she felt naked and false" (Adichie 5). Although writing from distinct (postcolonial) geographical locations (one in the Caribbean whose memories of the Middle Passage are carved in her lineage, and one, whose body is forced to detail a history of colonial exploitation and neo-colonial systems of slavery as a migrant to the west ${ }^{3}$ ), both Danticat and Adichie see the motif of weaving hair, which runs in their blood, as a complex site of emancipation. In Rivera's words, social discourse "grounds the hopes of those seeking transformation through creative practice" (Poetics of the Flesh 115). Interestingly, in the quotation, Danticat refers to this act of writing as a "testament." As seen, this echo of confessional writing is also detailed in Ifemelu's healing journey, which forms intriguing correlations with theopoetics, particularly as explored by Rivera.

\section{CONFRONTING COLONIAL TROPES: CARVING A SPACE FOR MATERIAL TRANSCENDENCE}

In Poetics of the Flesh, Rivera details how colonial discourses are immersed in the classification of people through the racialization of flesh, and how this racialization of flesh parallels the traditional theological tendency to see flesh as the cause of sinfulness (117). In the early pages of Americanah (as Ifemelu is having her hair braided, as detailed above) the reader is told that she has stopped writing the blog. Ifemelu begins to reminisce about her childhood and the journey to the United States; much of the rest of the novel is told in retrospect from the hairdresser's chair. The braider tugs on Ifemelu's hair with a comb, causing her to chastise the braider for using the wrong comb. Just like Danticat's narrator, it is at this point that she thinks about her mother:

2 All refererences to Adichie will be from the novel Americanah, unless stated otherwise.

3 See Adichie's lecture “The Danger of a Single Story.” 
Ifemelu had grown up in the shadow of her mother's hair. It was black-black, so thick it drank two containers of relaxer at the salon, so full it took hours under the hooded dryer, and when finally released from pink plastic rollers, sprang free and full, flowing down her back like a celebration. Her father called it a "crown of glory." "Is it your real hair?" strangers would ask, and then reach out and touch it reverently. (41)

The theological rhetoric used to describe Ifemelu's memories of her mother's hair is poignant; the "crown of glory" provides echoes of Christ but is also reminiscent of the dreadlocked hair in Rastafari (the AfricanCaribbean postcolonial imaginings criss-cross again). In the Rastafari context, the "crown of glory" is symbolic of Christ, but also the lion's mane of the Lion of Judah (referring to the lineage of Ras Tafari Makonen, the King of Ethiopia, and in Rastafari theology, the second Christ). This is woven with the Biblical stories of Samson's power being held in his hair, and the journeys of resistance and freedom by those enslaved, to signify their refusal to tame their hair to colonial standards of civility, to allow it to grow free. The dreaded hair is a vessel for power which physically distinguishes the Rasta from the oppressive and controlling systems of "Babylon" (white/western colonial/capitalist centres of power). Rivera details those [poets] who "strive to conjure other bodies," which can be extended to a reflection upon the Rastafari embodiment of Christ and a rejection of "Babylon" (Poetics of the Flesh 115). She goes on to say that these acts "are not the negation of their racialized features, but rather their emancipation ... creative practices such as these are vital for redeeming flesh" (115). The Rastafari "conjuring" of other bodies that resist the clothes, food, hairstyles of the imperial and "civilized" centre enables their emancipation. However, the language Adichie uses to describe Ifemelu's mother's hair as a "crown of glory," which at this point is not "natural" but chemically "relaxed," also signifies a complex history of Christian imperialism, as well as black emancipation and identity-formation.

In the following paragraph, however, Ifemelu describes the day her mother's relationship with her hair, and herself, changed:

One day, the year Ifemelu turned ten, her mother came home from work looking different. Her clothes were the same, a brown dress belted at the waist, but her face was flushed, her eyes unfocussed. "Where are the big scissors?" she asked, and when Ifemelu brought it to her, she raised it to her head and, handful by handful, chopped off all her hair. (41)

Ifemelu's mother proceeds to collect all of the Catholic objects from around her home, crucifixes, rosaries and burn them along with her hair: 
"I am saved," she said. "Mrs Ojo ministered to me this afternoon during the children's break and I have received Christ. Old things have passed away and all things have become new. Praise God. On Sunday we will start going to revival saints. It is a Bible-believing church and a living church, not like Saint Dominic's." Her mother's words were not her own... But after that afternoon, her God changed. He became exacting. Relaxed hair offended Him. Dancing offended Him. She bartered with Him, offering starvation in exchange for prosperity, for a job promotion, for good health. She fasted herself bone-thin. (41-42)

This extreme act of bodily purging connects to Christian traditions which saw flesh as a sign of sin. Within this context, racialized flesh and hair was part of "the production of colonialist knowledge and the concomitant structuring of global and local relations according to types of people, types of bodies" (Rivera, Poetics of the Flesh 116). A key part of the colonial project was the control of the body; in relation to Adichie's novel Purple Hibiscus, Corinne Sandwith writes: "At work here is not only the specific colonial project of disciplining the native body against the propensity for laziness or sexual excess, but also the foundational dualistic logic of Western philosophical discourse in which mind and body are polarized and hierarchized" (Sandwith 98). Here, western enlightenment values are aligned with Christian values through the colonial project and the promotion of Europe as the civilized centre. To control and discipline your body, particularly through suffering, and distance it from the superiority of the mind, is to be truly enlightened: "The Christian discourses of sin and redemption, exemplified in the suffering body of Christ, give privileged place to a view of the body as nobly and necessarily wounded in pursuit of purity, salvation, or the presence of God" (Sandwith 99). Black, and particularly female black, bodies were an ideal place for white (predominantly but not exclusively) male colonizers and Christian missionaries to promote (and often forcibly demonstrate) their notion of enlightenment. White colonial constructions of civility, closely linked to Christian notions of purity of the flesh, fixed the black body as a "degraded form of the human (animalistic, irrational, hypersexual)" which required "the continual exertion of vigilance and the ritualised humiliation of the flesh" (Sandwith 99). ${ }^{4}$ Here, Ifemelu's mother, with "eyes unfocussed" and "with words that were not her own" (Adichie 41) disciplines her (black

4 Refer also to the work of Kwok Pui-Lan who details the relationship between Christianization and westernization: "As colonial desire and imperialistic violence were masked and reconstituted in a blatant reversal as 'civilizing mission,' the Christian church played important roles through the sending of missionaries, establishing churches and schools, and propagating ideas of cleanliness and hygiene. Christianization and westernization became almost a synonymous process in the colonial period" (17). 
female) body to perform appropriately within the defined parameters of another righteous Christian notion of salvation and European civility. Rivera's discussion of theopoiesis aims to redeem the body from these limited constructions of divinity and transcendence, and therefore lead to incarnation (redeemed in the body not beyond it); "transcendence here does not point beyond the world but toward it" (Rivera, "Poetics Ashore" 244). This model of transcendence is guided by how words, poetics, are put into being through creative practice; how creative writers challenge accepted doctrine and carve spaces for new possibilities (Rivera, "Poetics Ashore" 242). The way in which Adichie weaves connections between the body, flesh, constructions of divinity and transcendence, and the discursive practice of writing, and themes of migration, lead toward "modes of knowing, being and acting in the world" (242). Eventually, Ifemelu's mother "left the church and began to let her hair grow again" after being guided by an angel (Adichie 43).

\section{THE BLOGOSPHERE AS SOCIAL DISCURSIVE PRACTICE}

A significant section of the novel is Ifemelu's own act of cutting off her hair in order to "go natural." The similarities with her mother's journey are evident, yet, ambiguous. Adichie draws together issues of Christianization, colonization, westernization, and I would argue, the conflicting journey towards Rivera's notion of material "transcendence" (pointing towards not beyond the world). In contemporary contexts, particularly for migrant women, like Ifemelu, hair is central to "Black women's acculturation and socialization, for it influences the concept(ion) of femininity. The binary opposite "good/bad" hair has for centuries been an epistemological tool used to juxtapose western and Black beauty, devaluing the latter and reinforcing European aesthetics" (Cruz-Gutiérrez 66). Black women, deemed as having "bad hair" are forced to engage in the performance to soften the image of black women for a white civilized audience, with "devastating effects in the identity-formation process" (67). Adichie details this devastation through the character of Ifemelu, whose mother, we have seen, was also traumatized by Eurocentric aesthetics (but distinctively within the (post)colonial Nigerian context). In her article, Cruz-Gutiérrez provides a clear history of black women's hair movements. The author establishes that we are currently in the third wave of the hair movements, and that Adichie's novel is a key commentary on this current wave (67-68). What is distinct about this third wave is the central role that the blogosphere and social media play in the formation of communities 
and in the dissemination of counter narratives which challenge dominant epistemological frameworks (67). Cruz-Gutiérrez argues that through her novel Americanah, Adichie explores how the internet, or the discursive practice of blogging, formulates a flexible and emancipatory space for black women to explore and celebrate their relationship with their hair (76). What Cruz-Gutiérrez does not reflect on, however, is the destructive effect that the blog writing process (under the identity-umbrella of "NonAmerican Black") begins to have on Ifemelu and her identity-formation, which is the point at which Adichie begins the story (as referenced earlier).

In her reading of Americanah, Camille Isaacs (2016) focuses on the more destructive elements of social media/blog writing for migrant women. She states that "cyberspace risks replicating the hierarchies of classical imperialism" (187). This importantly pays attention to the dangers of imagining a safe disembodied place (the internet) where we can find liberation, for the space of the internet is constructed and managed by capitalist and Eurocentric agendas. As Rivera reminds us, all discursive practice arises from the experiences of our bodies in the world, not in transcendence of it. Arjun Appadurai (2019) explores the possibility of modern, digital archives as a method of vocalization for migrants in the current Euro-American political climate. This mode of story-telling and memory-making will never be a simple liberation and will inevitably be bound by and in negotiation with the dominant, elitist narratives of nation-building. But within digital archives there exists the possibility for relationship with memory to shift and be re-worked so that migrants can be the narrators of their own stories, and potentially challenge imperial representations of migrant communities. Appadurai writes: "literate migrants have begun to explore social media, chat rooms, and other interactive spaces in which to find, debate, consolidate their own memory traces and stories into a more widely plausible narrative" (561). For those written out of national memory, on-line archives provide the possibility for formulating other "imagined communities" (561). Whilst there will always be stories of loss and abjection which potentially feed the elite imagination, he details the possibility of other stories, which increase agency, also being disseminated: "the diasporic archive, or the migrant archive, is increasingly characterised by the presence of voice, agency, and debate, rather than of mere reading, reception and interpellation" (562). The ultimate challenge that Appadurai highlights is how stories of abjection can become stories of aspiration (refuges will always be "supplicants," not "applicants"). Our models of citizenship are built on our relationship with the past ("birth, parenthood, and blood"); and this model will always be out of reach for refugees (564). But Appadurai sees possibility in the role of migrant archives "not only as a storehouse of memory but also as aspirational 
maps" to formulate affirmative narratives which may enable a "basis for secure citizenship" (564). This cannot happen, however, without a major revisioning of sovereign nation-building, a topic he admits has no easy solution, particularly within the parameters of his article (564).

These articles provide insightful reflections into the relationship Adichie creates between migration, the blogosphere and liberation. Within the work of Cruz-Gutiérrez and Isaacs, there is a tendency to gloss over the more complex aspect of the theologically significant language Adichie uses to describe Ifemelu's, and her mother's, transition to natural hair; this is not a straightforward notion of transcendence but rather details the tensions between Christian imperialism, abjection, social materiality and connections to an "other-worldly" divinity. When this language and story of becoming is analyzed alongside theopoiesis, which enables ambiguity to be part of the story, we see the possibility of connection with an earthly and embodied divinity. In relation to Caribbean writing, but which again seems utterly relevant to Adichie's work, Rivera states: "this poetics does not look to the heavens but to the world around us" ("Poetics Ashore" 246). Whilst it is naive and idealistic to imagine the blogosphere as a space free of imperialist structures, the work of Adichie and Appadurai allow space and possibility for counter narratives; there is the possibility of unusual intertextual engagements that are distinctive within the contemporary digital age, without glossing over the abjection contained within these narratives.

\section{IFEMELU'S “BECOMING”: CYBERSPACE AND TRANSCENDENCE}

For the remainder of the article I will focus on Ifemelu's journey of "incarnation" in relationship to the blogosphere. I will focus more attention on her language of material transcendence, which I understand as the process of poetic God-making that details the "material entanglement" of humans to each other and the universe (Keller 116). This entanglement allows space for both the embodiment of traumatic physical histories and incarnation. Ifemelu's story details the completion of her studies, and her economic and academic success, but also the constant threat of poverty and being a victim of racist abuse: her migrant black status often makes her unemployable. Following university, it is Ifemelu's white boyfriend, Curt, who manages to secure her an interview for a job: "in the midst of her gratitude, a small resentment: that Curt could, with a few calls, rearrange a world, have things slide into spaces that he wanted them to" (Adichie 202). A friend advices her to "lose the braids and straighten your hair. 
Nobody says this kind of stuff, but it matters" (202). A few years earlier, Ifemelu would have laughed and refused to believe this, but her experience as a "Non-American Black" tells her to accept this advice. She uses relaxant to smooth her hair which burns her scalp: "the smell of burning, of something organic dying which should not have died, had made her feel a sense of loss" (203). Adichie locates Ifemelu's grief explicitly in the decay of her flesh, exposing how "social constructions materialize ... ultimately in human flesh" (Rivera, "Poetics Ashore" 242). Her sense of loss is for her homeland, and more poignantly, for the de-humanizing effect of migrancy on black women's bodies, on their flesh, which carry the scars of social constructions of race and gender. When her boyfriend is horrified by what she has done, and the injury she has inflicted, she explains: "I need to look professional for this interview, and professional means straight is best but if it's going to be curly then it has to be the white kind of curly, loose curls or, at worst, spiral curls but never kinky" (Adichie 204). Later, after breezing through the job interview, the woman shakes her hand and says she would be a "wonderful fit" in the company: "Ifemelu wonders if the woman would have felt the same way had she walked into that office wearing her thick, kinky, God-given halo of hair, the Afro" (204).

Ifemelu's reflections on divinity deserve careful attention, as this is a theme which guides her to her online community and writing her own blog. As I have shown, it is often in postcolonial writing that different notions of God are formulated, narratives that attend to the body, flesh and materiality and are not restricted by dominant discourses or imperial classifications, and mind-body dualism. Interestingly, Ifemelu mimics her mother's actions after her hair starts to fall out because of the relaxant and her friend, Wambui, convinces her to embrace the beauty of her natural hair:

\footnotetext{
"Relaxing your hair is like being in prison. You're caged in. Your hair rules you" . . . Ifemelu found a pair of scissors. Wambui cut her hair, leaving only two inches, the new growth since her last relaxer. Ifemelu looked in the mirror. She was all big eyes and big head. At best, she looked like a boy: at worst, like an insect. (208)
}

She phones in sick to work for three days, unable to show herself. When she eventually goes to work, she is asked if it means something political or if she is a lesbian (211). It is at this point that she goes on a website dedicated to women who have decided to "go natural" and eventually posts her photo and a comment:

She wrote: Jamilah's words made me remember that there is nothing more beautiful than what God gave me. Others wrote responses, posting thumbup signs, telling her how much they liked the photo she had put up. She 
had never talked about God so much. Posting on the website was like giving testimony in church; the echoing roar of approval revived her. (213)

At the start of the novel, Ifemelu details her discomfort within the hair salon; this community is not the right space for Ifemelu where her diaspora identity is conflicted and raw. In this space she feels vulnerable and exposed. But through the discovery of an online community, Ifemelu initially finds a space where she can finally voice the layers of un-spoken injustices that haunt her "Non-American Black" identity. Significantly, Ifemelu describes this online experience "like giving testimony in church; the echoing roar of approval revived her." One cannot help but reflect back to Ifemelu's mother's "hair journey" in relation to Christian doctrine. For Ifemelu to visualize cyberspace as a church building during her own natural-hair epiphany, I would argue, is an acknowledgement by Adichie that the blogosphere is not a transcendent, disembodied space that is free of (Christian) imperial controls.

Ifemelu's body, through her hair, is marked by a complex history of Christian imperialism and westernization. The conflicting space of the church building (here synonymized by Ifemelu with the blogosphere community), which we saw with Ifemelu's mother, shows that we cannot completely transcend demeaning images of our bodies:

People whose bodies are marked negatively in the society in which they live intentionally seek to produce alternative models for being a body and create communities guided by them. Poetic writing is an example of a practice of creating ... imaginative spaces for the affirmation of corporeal possibilities ... Demeaning images of my body will still affect me, but they compete with other images, rather than claiming universal validity. (Rivera, Poetics of the Flesh 148)

Social-material transformations are possible but will always be linked to and affected by "histories we never knew and will never know" (152). Importantly, in the following paragraph, Ifemelu's "corporeal possibility" is affirmed in the everyday materiality of the world around her. She describes her moment of epiphany in terms of the mundane; this is transcendence and becoming within the concrete and organic details of the world around her:

On an unremarkable day in early Spring - the day was not bronzed with special light, nothing of any significance happened, and it was perhaps merely that time, as it often does, had transfigured her doubts-she looked in the mirror, sank her fingers into her hair, dense and spongy and glorious, and could not imagine it any other way. That simply, she fell in love with her hair. (213, emphasis mine) 
Adichie ensures Ifemelu's moment of epiphany and transfiguration is surrounded by the mundane and the bland. It is in the dull, concrete reality of the everyday where the subversion and the magic lies ${ }^{5}$ ("an unremarkable day, not bronzed with special light"). It is in her physical and emotional experience of the organic matter of her hair, surrounded by the everyday beauty of the world, where she finds epiphany. Godmaking/theopoiesis is the entanglement of humans with the earth and materiality.

It is from this point that Ifemelu creates her blog "Raceteenth or Curious Observations by a Non-American Black on the Subject of Blackness in America." It becomes a successful social commentary with articles such as "A Michelle Obama Shout-out Plus Hair as Race Metaphor" where she articulates a powerful counter-narrative to institutional racism: "If Michelle Obama got tired of all the heat and decided to go natural and appeared on TV with lots of woolly hair ... She would totally rock but poor Obama would certainly lose the independent vote" (Adichie 297). The blog provides sustenance, financially and spiritually, for Ifemelu for many years. But the negative social forces that always threaten to destroy an "affirmation of corporeal possibilities" (which aligns with Appadurai's hope for the role of digital migrant archives) finally cause her own "poetics of flesh" to turn on itself; she begins to "feel like a vulture hacking into the carcasses of people's stories" (5). As Rivera says, "the weight of centuries of racial mythologies falls on a person, and her body crumbles" (Poetics of the Flesh 156).

Ifemelu returns to Nigeria, carrying the signs of her diasporic identity; she has become an "Americanah." She learns to navigate this terrain and begins to write again. This time her blogs are about the glorious details of the everyday:

She wrote of the woman at the street corner in Victoria Island who joyously said, "Fine Aunty," when Ifemelu stopped to buy apples and oranges. She wrote about the views from her bedroom window: a white egret drooped on the compound wall, exhausted from heat; the gateman helping a hawker raise her tray to her head, an act so full of grace that she stood watching long after the hawker had walked away. (Adichie 475)

5 This is explored by Brenda Cooper in her book A New Generation of African Writers: Migration, Material Culture and Language (2008). She locates the "spiritual and the unseen" in the "everyday, the material, and the concrete" (20). Within postcolonial fiction, Cooper argues that this becomes a "narrative device" (21). It is a "refusal of the binary between the Imaginary and the Symbolic, the metaphorical and the metonymic" (21). 
Ifemelu's blog settles into a rhythmic poetics which provides an intimate embodied connection with nature (descriptions of a peacock's feathers "fanned like a giant halo" [473]), the material world, and the grace in the exchange and interconnectedness of human bodies. When she contacts her ex-boyfriend, Curt, and says she is still writing a blog, he asks if it is about race. She replies: "No, just about life. Race doesn't really work here. I feel like I got off the plane in Lagos and stopped being black" (476). Ifemelu's material transcendence can finally take place: "Still, she was at peace: to be home, to be writing her blog, to have discovered Lagos again. She had, finally, spun herself into being" (475). The novel draws to a close with a final image of Ifemelu having woven her whole self, not just her hair, into being. Rivera details the etymology of the word religion "religare" which means "to bind" to affirm the "religious duty" poetics embody by their commitment to the traumas of the past and so the writing takes on a "sacred aura" (Rivera, "Poetics Ashore" 244). Adichie's writing equally, through the metaphor of hair braiding (or binding) affirms a religiosity that dares to imagine the possibility of material transcendence, of spinning yourself into being, through the painful negotiation of the body with the socio-material world:

Never forgetting injustice, suffering, or failure, such a poetics seeks to participate in earthly relations, to become flesh. There is nothing less at stake in this commitment than the possibilities of becoming for those who have been condemned by the deprecation of flesh. (Rivera, Poetics of the Flesh 157)

Ifemelu's becoming is intimately connected to the deprecated journey of her flesh, and the flesh of the women before her. The poetics that Adichie weaves, or spins, is committed to the complex, and often contradictory, stories of injustice and hope that define being in the world, whilst necessarily defying tidy narratives and conclusive theologies.

\section{CONCLUSION}

This article has provided a distinct reading of Adichie's novel, Americanah. I have mobilized the theoretical context of theopoetics to argue that Adichie's use of the motif of hair braiding alongside the intertextual spaces of the contemporary digital age, signal possibilities of becoming. Rather than being opposed to the power of the conventional literary text, the blogosphere in Americanah signals the possibility of this contemporary discursive space as a "poetics of the flesh." Our bodies are intimately 
connected to the social-material world, and the discursive spaces we create, such as the blogosphere, provide the possibility of transformation and "incarnation" within the body, not beyond it. I have argued that the link that Adichie makes between Ifemelu's hair journey and blog-writing narrates this possibility of incarnation and can be productively defined as an act of theopoiesis.

\section{Works CiTED}

Adichie, Chimamanda Ngozi. Americanah. London: Harper Collins, 2013. Print.

Adichie, Chimamanda Ngozi. "The Danger of the Single Story." Online video clip. Ted.com. TED Ideas Worth Spreading July 2009. Web. 5 Mar. 2020.

Appadurai, Arjun. "Traumatic Exit, Identity Narratives, and the Ethics of Hospitality." Television and Nerw Media 20.6 (2019): 558-65. Web. 22 Oct. 2019. https://doi.org/10.1177/1527476419857678

Cooper, Brenda. A New Generation of African Writers: Migration, Material Culture and Language. Suffolk: James Curry U of KwaZulu-Natal P, 2008. Print.

Cruz-Gutiérrez, Cristina. "Hair Politics in the Blogosphere: Safe Spaces and the Politics of Self-representation in Chimamanda Adichie's Americanah." Journal of Postcolonial Writing 55. 1 (2019): 66-79. Web. 22 Oct. 2019. https://doi.org/10.1080/17449855.2018.1462243

Danticat, Edwidge. Krik? Krak! New York: Soho,1991. Print.

Isaacs, Camille. "Mediating Women's Globalized Existence through Social Media in the Work of Adichie and Bulawayo." Safundi 17.2 (2016): 17488. Web. 22 Oct. 2019. https://doi.org/10.1080/17533171.2016.1179463

Keller, Catherine. Intercarnations. Exercises in Theological Possibility. Fordham.universitypressscholarship.com. Fordham Scholarship Online Jan. 2018. Web. 5 Mar. 2020.

Pui-Lan, Kwok. Postcolonial Imagination and Feminist Theology. London: SCM, 2005. Print.

Rivera, Mayra "Poetics Ashore." Literature and Theology: A Special Issue on Theopoetics 33.3 (2019): 241-47. Print. https://doi.org/10.1093/ litthe/frzO25

Rivera, Mayra "Poetics Ashore." Poetics of the Flesh. Durham: Duke UP, 2015. Print.

Sandwith, Corinne. "Frailties of the Flesh: Observing the Body in Chimamanda Ngozi Adichie's Purple Hibiscus." Research in African Literatures 47.1 (2016): 95-108. Web. 4 Sept. 2019. https://doi. org/10.2979/reseafrilite.47.1.95 
Fiona Darroch is Book Reviews Editor for Literature and Theology: An International Journal of Religion, Theory and Culture (Oxford University Press). She is a lecturer in Religion at the University of Stirling, Scotland, and author of articles such as “'Ou libéré?' Vodou and Haiti: Speaking the Language of Resistance, Remembrance and Freedom in the Writing of Edwidge Danticat" in Translating Wor $(l) d s$ : Christianity across Cultural Boundaries (Collectanea Instituti Anthropos. Ed. Sabine Dedenbach-Salazar Sáenz. Baden-Baden: Academia/Nomos, 2019); and "Re-imagining the Sacred in Caribbean Literature" in Literature and Theology: New Interdisciplinary Spaces edited by Heather Walton (London: Ashgate, 2011); and the monograph Memory and Myth: Postcolonial Religion in Contemporary Guyanese Fiction and Poetry (Amsterdam: Rodopi, 2009).

ORCID: 0000-0003-4424-2506

fiona.darroch@stir.ac.uk 